\title{
PELATIHAN DAN SOSIALISASI E-COMMERCE USAHA KECIL KULINER DI KELURAHAN PADANGSAMBIAN
}

\author{
N.KA. Wirdiani ${ }^{1}$, A.A.K.O. Sudana ${ }^{2}$, N.K.D. Rusjayanthi ${ }^{3}$ dan D.P.Githa
}

\begin{abstract}
ABSTRAK
Penggunaan media internet dipilih dalam bisnis e-commerce karena sifatnya yang praktis dan efektif serta internet memiliki jaringan publik yang artinya memiliki harga murah, tapi sangat cepat dan juga mudah dalam mengaksesnya [Janice, 2004]. Penggunaan media internet khususnya e-commerce akan mempermudah, memperluas dan meningkatkan akses, jangkauan serta layanan kepada pelanggan.Kemajuan teknologi komputer, multimedia dan smartphone memberi peluang besar bagi pengusaha Usaha Kecil khususnya pengusaha kuliner makanan dan minuman tradisional, seperti Nasi Jinggo, Nasi Yasa, Ketipat Cantok, Jukut Plecing, Daluman dan lain-lain di Kelurahan Padangsambian, untuk dapat memanfaatkan teknologi sebagai sarana perbaikan tata kelola pemasaran sehingga dapat dikenal lebih luas. Berdasarkan permasalahan tersebut dibuatlah Sistem e-Commerce Usaha Kecil Kuliner. Pada e-Commerce terdapat fitur vendor dan user. Vendor dapat mendaftarkan produknya dan melihat daftar pesanan sedangkan user dapat memilih produk yang diinginkan kemudian menambahkan ke Cart dan melakukan transaksi pembayaran.
\end{abstract}

Kata kunci: teknologi informasi, tata kelola dan sistem pemasaran, E-commerce, usaha kuliner tradisional.

\begin{abstract}
The use of internet media is chosen in e-commerce business because of its practical and effective nature and the internet has a public network which means it has low prices, but is very fast and also easy to access. The use of internet media especially e-commerce will facilitate, expand and improve access, reach and services to customers. The advancement of computer technology, multimedia and smartphones provides a great opportunity for Small Business entrepreneurs, especially culinary entrepreneurs in traditional food and beverages, such as Nasi Jinggo, Nasi Yasa, Cantok Ketipat, Jukut Plecing, Daluman and others in Padangsambian Village, to be able to use technology as a means of improving marketing governance so that it can be more widely known. Based on these problems, the Culinary Small Business e-Commerce System was created. In e-Commerce there are vendor and user features. Vendors can register their products and view order lists while users can choose the desired product then add to the cart and make payment transactions.

Keywords: information technology, governance and marketing systems, E-commerce, traditional culinary efforts.

\footnotetext{
${ }^{1}$ Program Studi Teknologi Informasi Fakultas Teknik Universitas Udayana, ayuwirdiani@unud.ac.id

${ }^{2}$ Program Studi Teknologi Informasi Fakultas Teknik Universitas Udayana, agungokas@unud.ac.id

${ }^{3}$ Program Studi Teknologi Informasi Fakultas Teknik Universitas Udayana, dwi.rusjayanthi@ unud.ac.id

${ }^{4}$ Program Studi Teknologi Informasi Fakultas Teknik Universitas Udayana, dwiputragitha@unud.ac.id
} 


\section{PENDAHULUAN}

Usaha Kuliner saat ini masih sangat diminati oleh pengusaha kecil karena makanan dan minuman merupakan kebutuhan primer masyarakat. Usaha Kuliner nasi jinggo merupakan salah satu Usaha Kecil yang menjanjikan karena dengan modal 1-2 juta maka sudah bisa mengambil peluang usaha ini. Nasi Jinggo merupakan kuliner berupa nasi lengkap dengan lauk pauknya yang diungkus dengan daun pisang. Nasi Jinggo saat ini masih menjadi pilihan untuk semua kalangan mulai dari anak-anak hingga dewasa. Nasi Jinggo disajikan berbagai macam pelengkap mulai dari serundeng, mie goreng, ayam bumbu pedas, telur juga bahan pelengkap lainnya. Penggemar Nasi Jinggo masih sangat banyak sehingga membuat speluang bisnis Nasi Jinggo sangat menjanjikan. Salah satu usaha kuliner Nasi Jinggo di Wilayah Padangsambian adalah Warung Spesial Nasi Jinggo dan Jus. Warung ini menyediakan berbagai macam varian nasi jinggo seperti Nasi Jinggo Ayam Bakar, Nasi Jinggo Sambel Plecing, Nasi Jinggo Beras Merah, Nasi Jinggo Babi Kecap, serta Nasi Jinggo Sapi. Selain menyediakan nasi jinggo, warung ini juga menyediakan berbagai minuman seperti Juice, Es Teler, Es buah dan lain sebagainya. Warung ini memiliki beberapa cabang dengan jumlah karyawan 12 orang.

Kendala yang dihadapi oleh usaha Nasi Jinggo ini adalah tingkat persaingan yang tinggi dan ketat selain itu proses promosinya masih dilakukan secara konvensional. Guna mengatasi permasalahan dari persaingan yang tinggi dan keterbatasan jangkauan pemasaran Nasi Jinggo dan Jus yang dialami oleh pengusaha kecil kuliner maka dikembangkan E-Commerce Nasi Jinggo dan Jus. Melalui sistem ini dapat memudahkan orang untuk melakukan pemesanan dimana saja dan kapan saja. Toko online ini merupakan alternatif belanja yang praktis untuk konsumen [Taufik, 2008]. Beberapa penelitian yang menggunakan e-commerce dalam meningkat pemasaran produknya adalah penelitian oleh Diki Susandi yang menggunakan e-commerce sebagai sarana untuk memasarkan Distro Dlapak Street Wear [Diki, 2017]. Hani Atun yang melakukan uji coba dan evaluasi pada Koperasi mahasiswa STT Dharma Iswara Madiun yang memanfaatkan e-commerce sehingga dapat meningkatkan pendapatan koperasi tersebut [Hani, 2017]. Nuryanti yang melakukan analisis pemanfaatan e-commerce untuk meningkatkan daya saing usaha kecil dan meningah (UKM) [Nuryanti, 2013]. Penelitian yang dilakukan oleh Shabur Miftah yang mengimplementasikan e-commerce pada Toko Pastbrik Kota Malang sehingga dapat menginformasikan produk secara cepat ke pelanggan dan meningkatkan pendapatan [Shabur, 2015].

Berdasarkan hal tersebut maka sistem E-Commerce yang dibuat oleh civitas akademika Universitas Udayana Program Studi Teknologi Informasi disosialisasikan dan dimanfaatkan untuk dapat membantu Pengusaha Kecil Kuliner dalam memasarkan dan menjual produknya sehingga dapat dikenal secara lebih luas.

\section{METODE PELAKSANAAN}

Pendekatan yang ditawarkan untuk menyelesaikan persoalan yang dihadapi Usaha Kecil Kuliner ini adalah dengan mengubah model penjualan dari yang bersifat konvensional dan lokal menjadi penjualan global dengan memanfaatkan Sistem Informasi Manajemen dalam bentuk e-Commerce. Sistem Informasi Manajemen merupakan bidang kajian yang saat ini sedang berkembang seiring dengan perkembangan dunia

bisnis dan kemajuan teknologi informasi sebagai pendukung dari aktivitas bisnis [Loudon, 2007]. Cara implementasi yang digunakan adalah dengan melaksanakan pelatihan dan pendampingan penggunaan Aplikasi E-Commerce Kuliner Tradisional, dengan memanfaatkan penggunaan teknologi informasi. Evaluasi pelaksanaan memantau perkembangan bisnis setelah penerapan sistem secara berkelanjutan. 


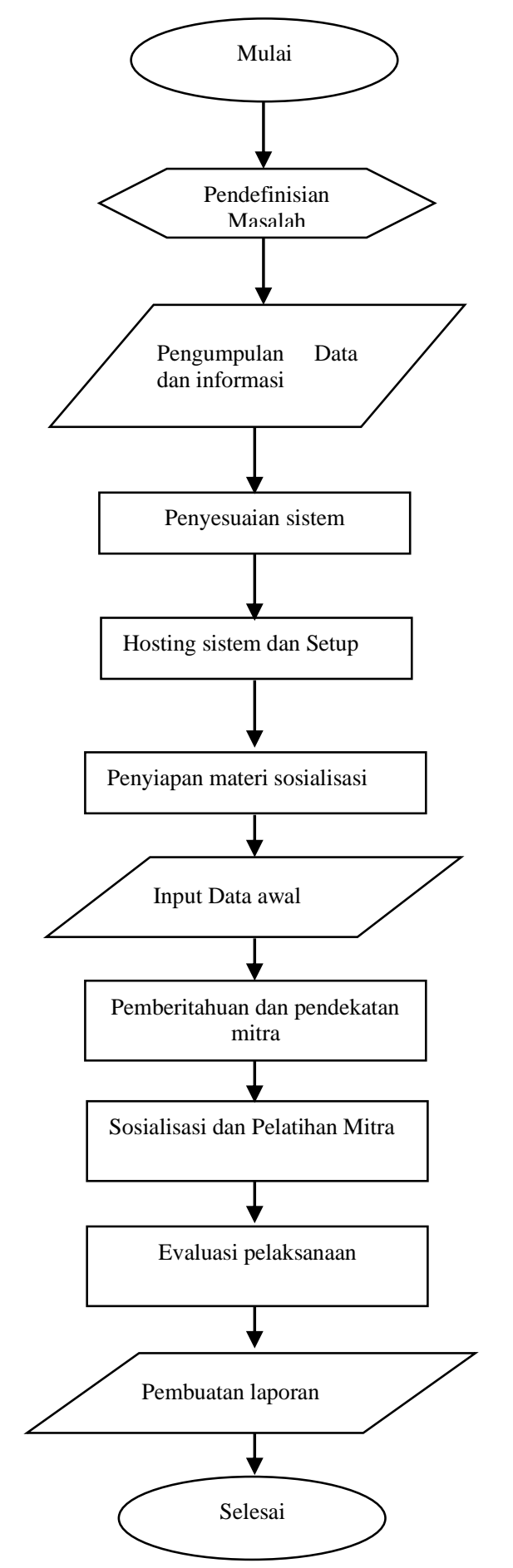

Gambar 1. Tahapan Pelaksanaan Kegiatan

\section{HASIL DAN PEMBAHASAN}

Tahapan awal yang dilakukan dari pengembangan sistem ini adalah melakukan survey untuk memperoleh informasi bisnis proses, model tata kelola, metode pemasaran dan penjualan yang dikembangkan oleh Warung Spesial Jinggo dan Juice. Pada tahapan ini diperoleh informasi bahwa bisnis kuliner ini masih menggunakan proses pemasaran dengan penjualan langsung dan kalaupun ada orderan yang minta diantar masih melalui telepon. Kendala yang dihadapi dari usaha Kecil ini adalah jangkauan penjualan produk 
kuliner yang saat ini masih melayani secara lokal. Pembuatan suatu perangkat lunak e-commerce Kuliner Tradisional berbasis web, yang bisa diakses secara online berfungsi untuk meningkatan pemasaran produk kuliner tradisional yang berimbas meningkatnya penjualan. Sistem e-commerce ini juga memudahkan masyarakat umum untuk memesan kuliner tradional dan melakukan transaksi pemesanan secara online. Berikut adalah foto-foto kegiatan pada waktu pengabdian:

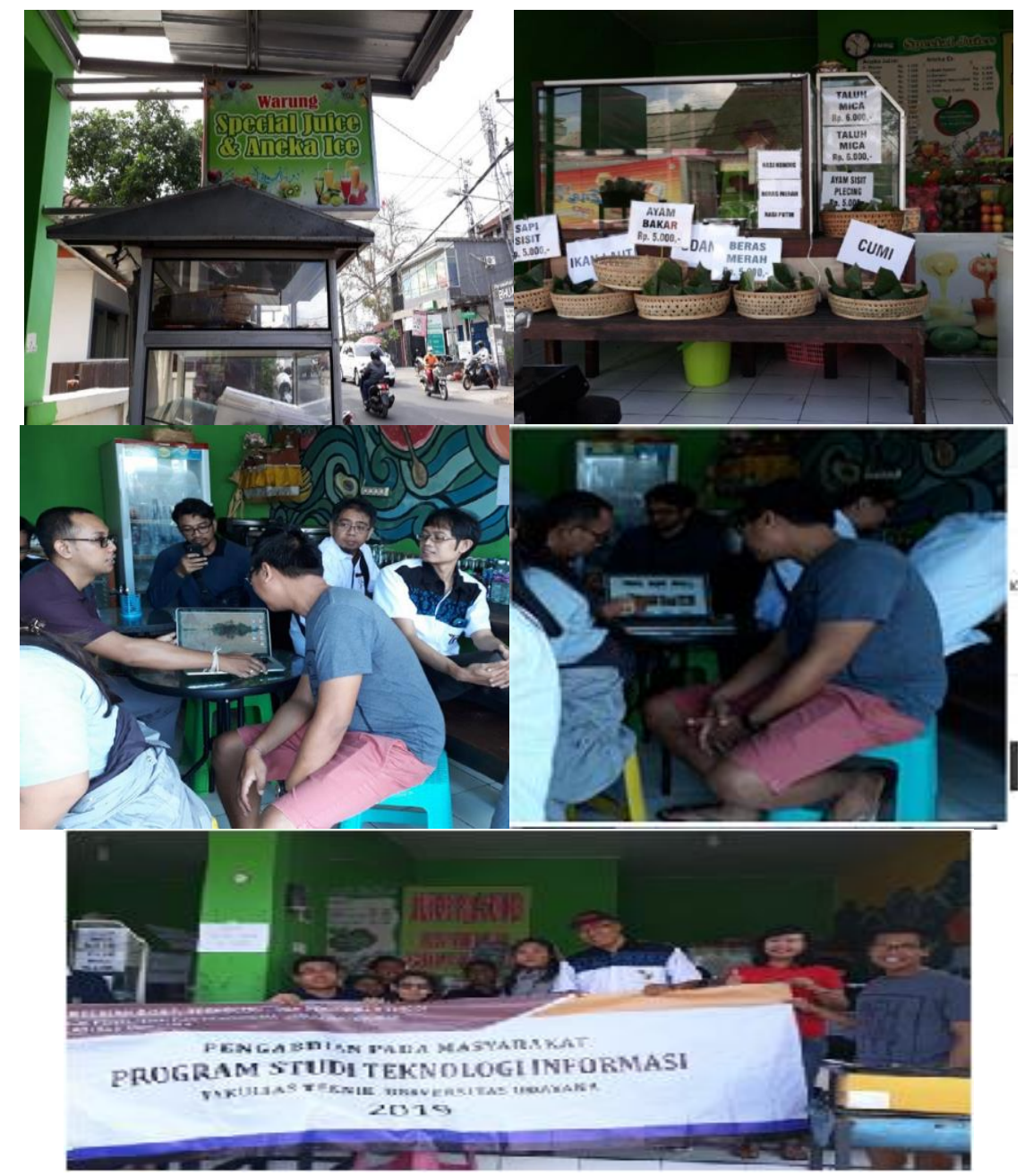

Gambar 2. Sosialisasi dan Pendampingan penggunaan Aplikasi e-commerce

\subsection{Tampilan Aplikasi dan Penggunaan Sistem}

Pada tahapan ini pengembangan sistem e-commerce yang dilakukan sudah menyesuaikan dengan yang diinginkan oleh mitra. Website e-commerce ini dibuat dengan menggunakan php dan mysql [Edi, 2011], [Taryana, 2007]. Berikut adalah penjelasan tentang bagaimana cara menggunakan aplikasi e-commerce tersebut secara singkat:

1. Akses Sistem Informasi 
Sistem Informasi Penjualan Baju Barong berbasis web dapat diakses pada alamat https://sanatras.com/di jaringan internet.

2. Cara Penggunaan Aplikasi sebagai Pengelola/Admin

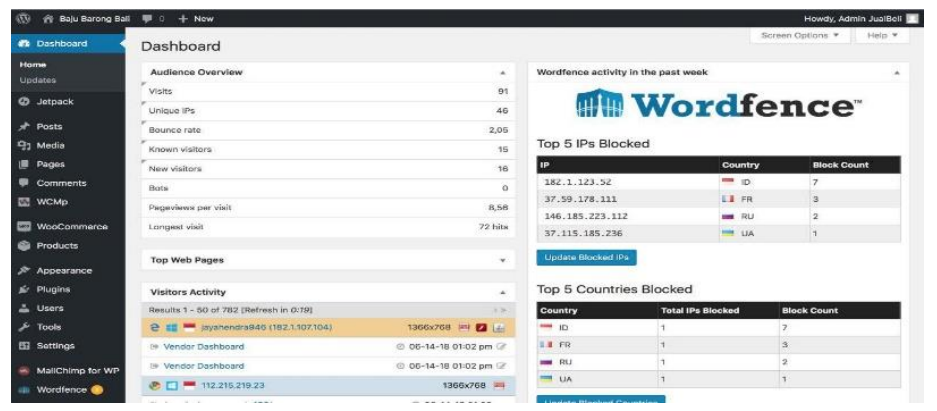

Gambar 4. Halaman Pengelola (Admin)

Gambar 4 menampilkan halaman awal yang muncul ketika admin sudah berhasil melakukan login. Terdapat banyak pilihan menu dalam mengelola aplikasi pada sisi admin.

3. Cara Penggunaan Aplikasi (Penjual/Vendor)

Penjual yang menggunakan aplikasi ini untuk memasarkan dan menjual produknya hanya perlu masuk ke alamat https://sanatras.com/ dan mendaftarkan diri sebagai Vendor kemudian Admin akan memverifikasinya.

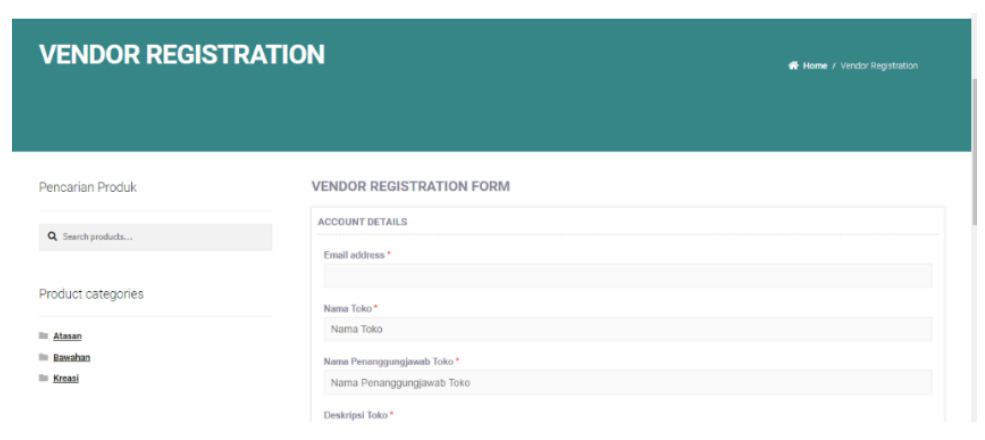

Gambar 5. Halaman Registrasi Vendor

Gambar 5 menampilkan halaman ketika user ingin bergabung menjadi Vendor (penjual). User terlebih dahulu harus melengkapi formulir pendaftaran dan setelah itu menunggu verifikasi dari pihak Admin. 


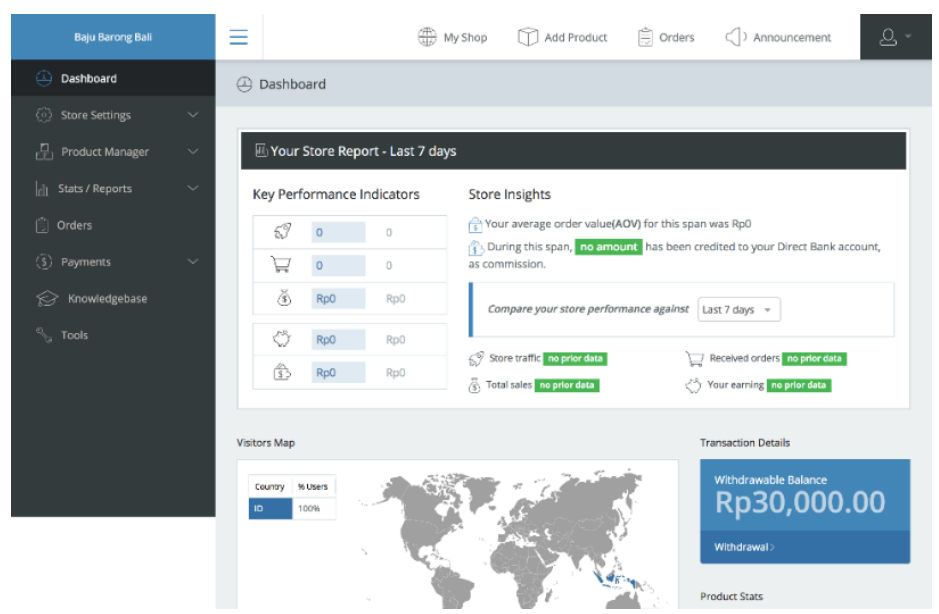

Gambar 6. Halaman Awal Vendor (Penjual)

Gambar 6 merupakan tampilan dari halaman Vendor ketika sudah di verifikasi oleh pihak Admin. Vendor (Penjual) sudah bisa melakukkan aktifitas penjualan, seperti menambahkan produk yang akan dijual dan informasi vendor lainnya.

\section{Cara Penggunaan Aplikasi (Pembeli)}

Pembeli yang menggunkan aplikasi ini hanya perlu masuk ke alamat https://sanatras.com dan selanjutnya memilih kuliner yang diinginkan.

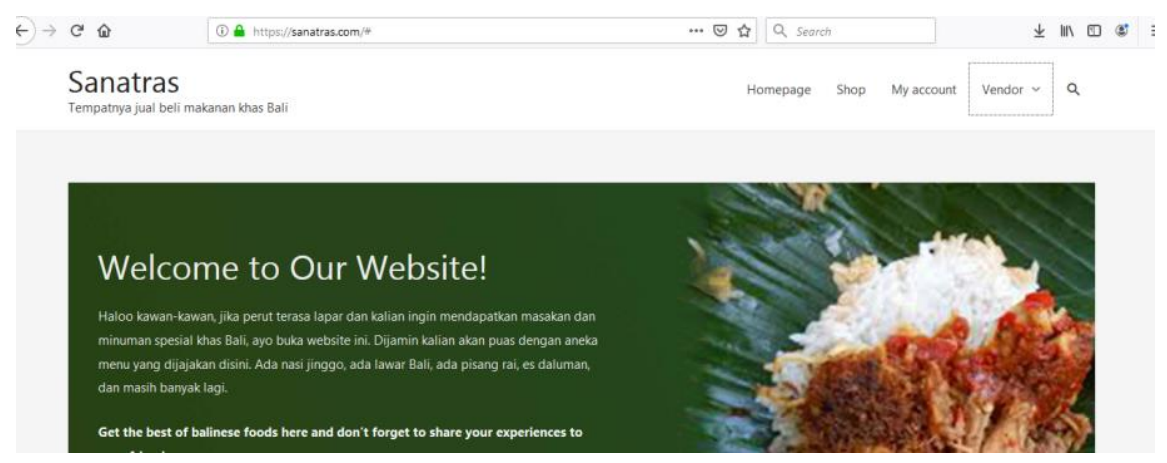

Gambar 7. Halaman Awal e-Commerce kuliner tradisional

Gambar 7 adalah Halaman Awal -Commerce kuliner tradisional. User dapat memilih makanan apa saja yang ditampilkan oleh berbagai penjual dan melakukan transaksi.

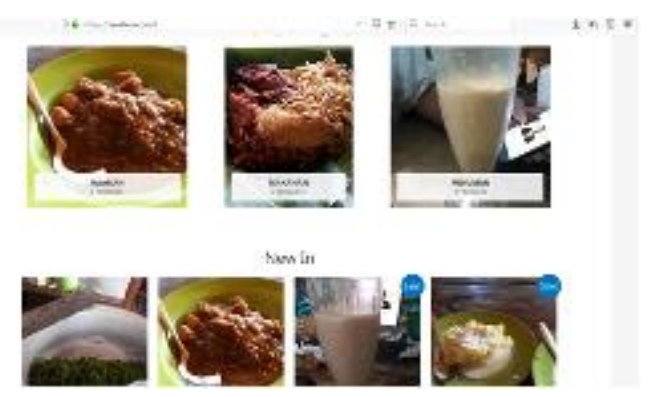

Gambar 8. Tampilan Produk Kuliner 
Gambar 8 merupakan tampilan dari produk kuliner. Pada halaman tersebut terdapat informasi mengenai produk kuliner dan harga dari produk tersebut.
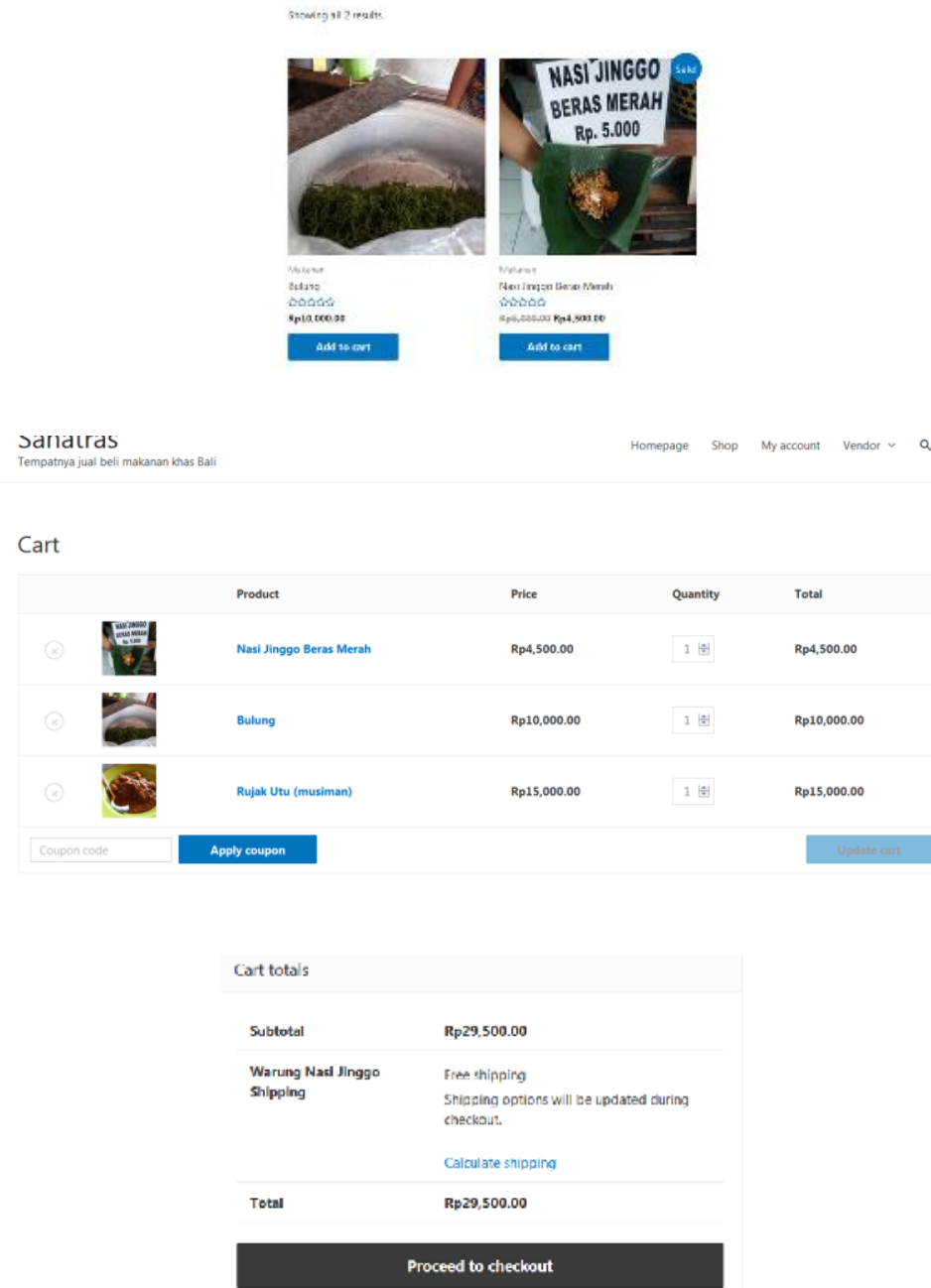

Gambar 11. Tampilan Halaman View Cart

Gambar 11 merupakan tampilan dari halaman View Cart. Pada halaman tersebut terdapat informasi mengenai total transaksi dan melakukan proses transaksi lebih lanjut.

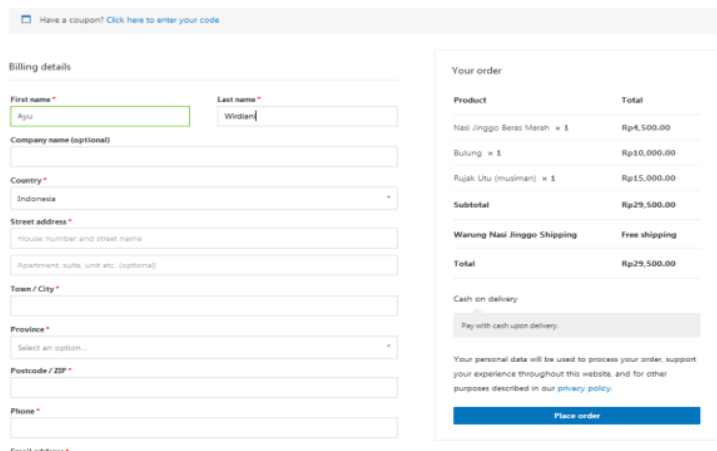

Gambar 12. Tampilan Halaman Proses Pembayaran 
Gambar 12 merupakan tampilan dari Proses Pembayaran. Pada halaman tersebut terdapat informasi mengenai informasi pembeli dan pembeli harus melakukan Login terlebih dahulu sebelum melanjutkan proses transaksi. Pada halaman ini juga terdapat detail pembelanjaan dan terdapat pilihan pembayaran yang ingin dilakukan oleh pembeli. Bila semua sudah diisi dan dipilih maka barang siap di kirim oleh pihak penjual.

\section{KESIMPULAN}

Aplikasi E-Commerce kuliner tradisional diharapkan mampu meningkatkan jangkauan penjualan produk kuliner tradisional yang saat ini masih bersifat lokal, untuk selanjutnya bisa lebih luas dengan dukungan teknologi informasi, khususnya pemasaran melalui internet. Aplikasi E-Commerce kuliner tradisional memudahkan masyarakat umum untuk mendapatkan informasi kuliner tradisional yang ada dan melakukan transaksi pemesanan secara online. Aplikasi E-Commerce kuliner tradisional mampu memperkenalkan karyakarya yang civitas akademika kampus kepada masyarakat luas, sehingga diketahui dan bisa dimanfaatkan, tidak hanya tersimpan dan dikenal dikalangan internal kampus saja.

\section{UCAPAN TERIMA KASIH}

Terimakasih kami ucapkan kepada LPPM Universitas Udayana yang membiayai kegiatan pengabdian ini, para pemilik usaha kuliner di Padangsambian dan Civitas Program Studi Teknologi Informasi, Fakultas Teknik, Universitas Udayana.

\section{DAFTAR PUSTAKA}

Diki Susandi, Sukisno, Sistem Penjualan Berbasis E-Commerce Menggunakan Metode Objek Oriented pada Distro Dlapak Street Wear, Jurnal Sistem Informasi, Vol. 4 Agustus 2017, pp.5-8

Edy Winarno, Smitdev Community, 2011, Mudah Membuat Website \& E-Commerce dengan PHP Framework, Elex Media Komputindo, Jakarta.

Hidayat, Taufik, 2008, Panduan Membuat Toko Online dengan OSCommerce, Mediakita, Jakarta.

Janice Reynolds, 2004, The Complete E-Commerce Book-Design, Build \& Maintain a Successful WebBased Business, CMP Media, Canada.

Hani Atun Mumtahana, Sekreningsih Nita, Adzinta Winerawan Tito, Pemanfaatan Web E-Commerce untuk Meningkatkan Strategi Pemasaran, Khasanah Informatika: Jurnal Ilmiah Teknik Informatika, Vol.03 No. 01 Juni 2017, pp. 6-15.

Laudon, Kenneth C, dkk, 2007, Sistem Informasi Manajemen Edisi 10 Buku 2, Salemba Empat, Jakarta. Nuryanti, Peran E-Commerce untuk Meningkatkan Daya Saing Usaha Kecil dan Menengah (UKM), Jurnal Ekonomi, Vol. 10 No. 4 Desember 2013, pp. 1-15.

Shabur M. Maulana, Heru Susilo, Riyadi, Implementasi E-Commerce Sebagai Media Penjualan Online (Studi Kasus Pada Toko Pastbrik Kota Malang), Jurnal Administrasi Bisnis (JAB), Vol. 29 No. 1 Desember 2015, pp. 1-9.

Taryana Suryana - Jonathan Sarwono, 2007. e-Commerce Menggunakan PHP \& MySQL, Graha Ilmu, Yogyakarta. 